\title{
Geological study of Chatara-Barahakshetra section, Sunsari-Udayapur District, eastern Nepal
}

\author{
*Drona Adhikari ${ }^{1,2}$, Keshav Shrestha $^{1}$, Purushottam Adhikari ${ }^{1,3}$, Khum N. Paudayal $^{1}$, and Lalu Paudel ${ }^{1}$ \\ ${ }^{1}$ Central Department of Geology, Tribhuvan University, Kirtipur, Kathmandu, Nepal \\ ${ }^{2}$ Central Campus of Technology, Tribhuvan University, Dharan, Sunsari, Nepal \\ ${ }^{3}$ Department of Geology, Birendra Multiple Campus, Tribhuvan University, Bharatpur, Chitwan, Nepal
}

\begin{abstract}
Geological mapping was carried out in the Chatara-Barahakshetra area of east Nepal. The Siwalik of the Chatara-Barahakshetra area is divided into the Lower Siwalik and the Middle Siwalik. Each unit is further subdivided into lower and upper members. The Central Churia Thrust is overturned in the study area. Highly deformed Siwalik contain several outcrop-scale as well as a large-scale folds.
\end{abstract}

Key words: Siwalik, Central Churia Thrust, deformed, fold

Received: 21 March 2018

Accepted: 19 June 2018

\section{INTRODUCTION}

Nepal Himalaya is the longest and youngest mountain system of the world (Gansser 1964). The Himalayan orogen has been the place of attraction for geologists worldwide (Searle et al. 1997; Clift et al. 2002; Yin 2006; Bouilhol et al. 2013; Chatterjee et al. 2013). Morphotectonically, the Himalaya has been further divided into Indo-Gangetic Plain or Terai, SubHimalaya or Siwalik or Churia, Lesser Himalaya, Higher Himalaya, and Tibetan-Tethys Himalaya (Gansser 1964; Frank and Fuchs 1970; Stöcklin 1980). The Sub-Himalaya or the Siwalik, is former foreland basin of the Himalaya, comprising of molasse-like sedimentary succession which reflects the rising history of the Himalaya (Gansser 1964). In Nepal, the Siwalik succession is 4-6 km thick and represents coarsening upward sequence of rocks, i.e. shale, mudstone, siltstone, fine sandstone at basal part, followed by medium to coarse salt-pepper sandstone, pebbly-sandstone at middle section, while pebble-cobble to boulder conglomerate at the upper section, with fining up individual cycles. The lower part comprises finer, more mature sediments indicating the low relief for provenance. The increasingly coarse and immature sediments in the upper parts represent the rapid upliftment of the Himalaya with succeeding tectonic impulses (Sah 2015). The systematic classification of this sedimentary sequence was done by Pilgrim $(1910,1913)$ on the basis of vertebrate fossils study in Potwar Basin of western Himalaya. He divided the sequence into Lower, Middle and Upper Siwalik subgroups. Later on, Colbert (1934) and Kumar (1985) subdivided the

\footnotetext{
*Corresponding author

Eamil: dronaadhikari92@gmail.com (D. Adhikari)
}

Siwalik in local geological formations. Dhakal (2001) and Ulak (2004) slightly modified the classification introducing members on the basis of mudstone and sandstone proportion in case of the Lower Siwalik, and on presence/absence of pebbles in sandstone in the Middle Siwalik of Chatara-Barahakshetra section which has been adopted in present research work. According to Ulak (2004), the sedimentary sequence of the Siwalik of Chatara section is composed of coarsening upward sequence of rocks. The basal part consists of alternating beds of variegated mudstone, siltstone, fine sandstone, and is followed by salt-and-pepper sandstone and pebbly sandstone in the upper section. Foreset bedding, cross laminations suggest the meandering river deposit in basal section whereas coarse thick sedimentation in upper part indicates the braided form of river system. Detail lithological sections, petrography and route map in larger scale helps the further unveil of geological information. Structurally, the Siwalik section is bounded by the Main Boundary Thrust (MBT) in the north and the Himalayan Frontal Thrust (HFT) in the south. The Central Churia Thrust (CCT) makes the Siwalik sequence thicker as it carries the Lower Siwalik over the rocks of the Middle Siwalik (Auden 1935; Hagen 1969; Dhital 1992; Sunuwar 1993; Ulak 2004; Dhital 2015). The Petroleum Exploration Promotion Project (PEPP) map of block 10 has shown anticline and syncline masses to the east area of the present study area, of which the extension is not till justified. The detail structural mapping in larger scale helps to reveal the minute structural details which is still lacking in the area. Present study is focused on the geological mapping, to establish detailed lithostratigraphy, structural analysis of the Siwalik section of Chatara-Barahakshetra area and its location shows in Fig. 1. 


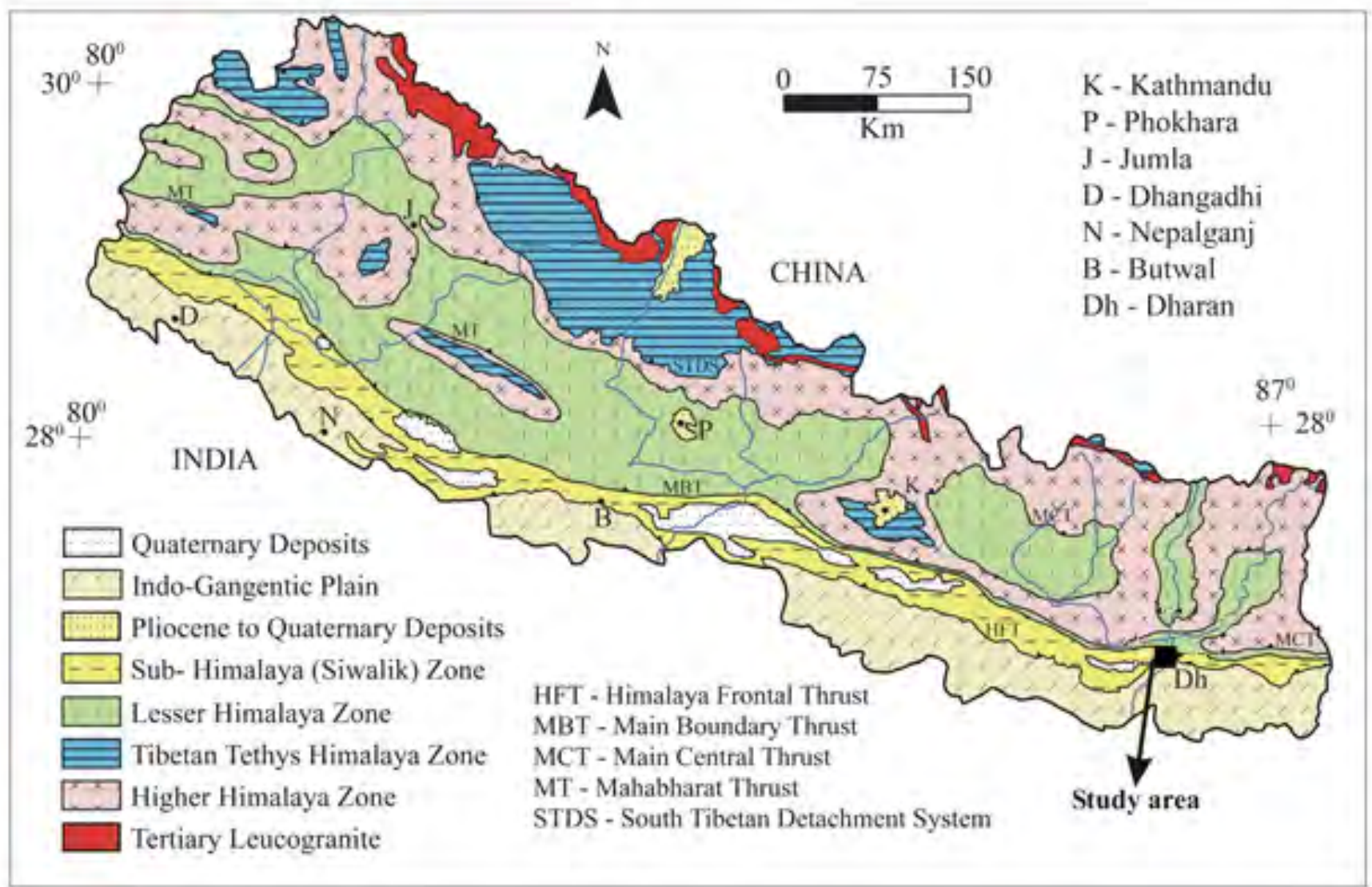

Fig. 1: Location of study area (modified after Martin et al. 2005).

\section{METHODOLOGY}

The study was conducted in 4 phases: desk study, field study, lab study and analytical works. Topographical map of Chatara at a scale of 1:25000 (Department of Survey 2687 01D) was used as the base map to add the collected geological data in the field. General geological instruments were used during the field works (Brunton compass, geological hammer, dilute $\mathrm{HCl}$, measuring tapes of various lengths, chisel etc). During the lab works thin sections were prepared following the standard thin section preparation techniques described by Paudel (2011). The prepared thin sections were observed at 40x magnification under petrological Olympus Microscope. More than ten random field of views were observed for petrographic analysis of the thin sections. The petrographic analyses were based on Paudel (2011).The photomicrographs of the thin sections were taken with digital eye-piece camera with Motic Plus Software. Different graphical as well as data analysis tools/programs such as ArcGIS 10 (student version), CorelDRAW, MsExcel, etc were used to digitize the map and analyze the collected data.

\section{RESULTS}

\section{Lithostratigraphy}

The rocks of the Siwalik Group are outcropped along the Chatara-Barahakshetra road between the Chatara and the Kokaha Khola, which are bounded by the sediments of the
Indo-Gangetic Plain in the south and metasedimentary dolomite (Lukwa Dolomite) and quartzite (Sapt Koshi Formation) in the north. The Siwalik Sequence in the Chatara-Barahakshetra area has been further divided into the Lower Siwalik and the Middle Siwalik (Fig. 2).

\section{Lower Siwalik}

The Lower Siwalik can be observed between the Chatara and the Bahune Khola along the Chatara-Barahakshetra road, and at Dumre, Champapur upto Kothu villages. The Lower Siwalik comprises of greenish grey, bluish grey to grey, fineto medium-grained sandstones, variegated mudstones and siltstones. It is bounded by the HFT in south and in north it transitionally passes to the rocks of the Middle Siwalik. Based on the proportion of mudstone and sandstone, mineralogical composition, grain size and texture, the Lower Siwalik is further divided into two divisions. The studied thickness of the Lower Siwalik is $750 \mathrm{~m}$.

\section{Lower Member}

In this section the proportion of the mudstone is high in comparison to sandstone. The rocks of this member are wellexposed in the Bhandaritar, the Rani Khola and the Bagundre Khola and the Barahakshetra area. It consists of variegated mudstone, greenish grey to dark siltstone and fine grained sandstone (Figs. 3a and 4a). The thickness of mudstone and sandstone beds ranges from $20 \mathrm{~cm}$ to $480 \mathrm{~cm}$ and $20 \mathrm{~cm}$ to 

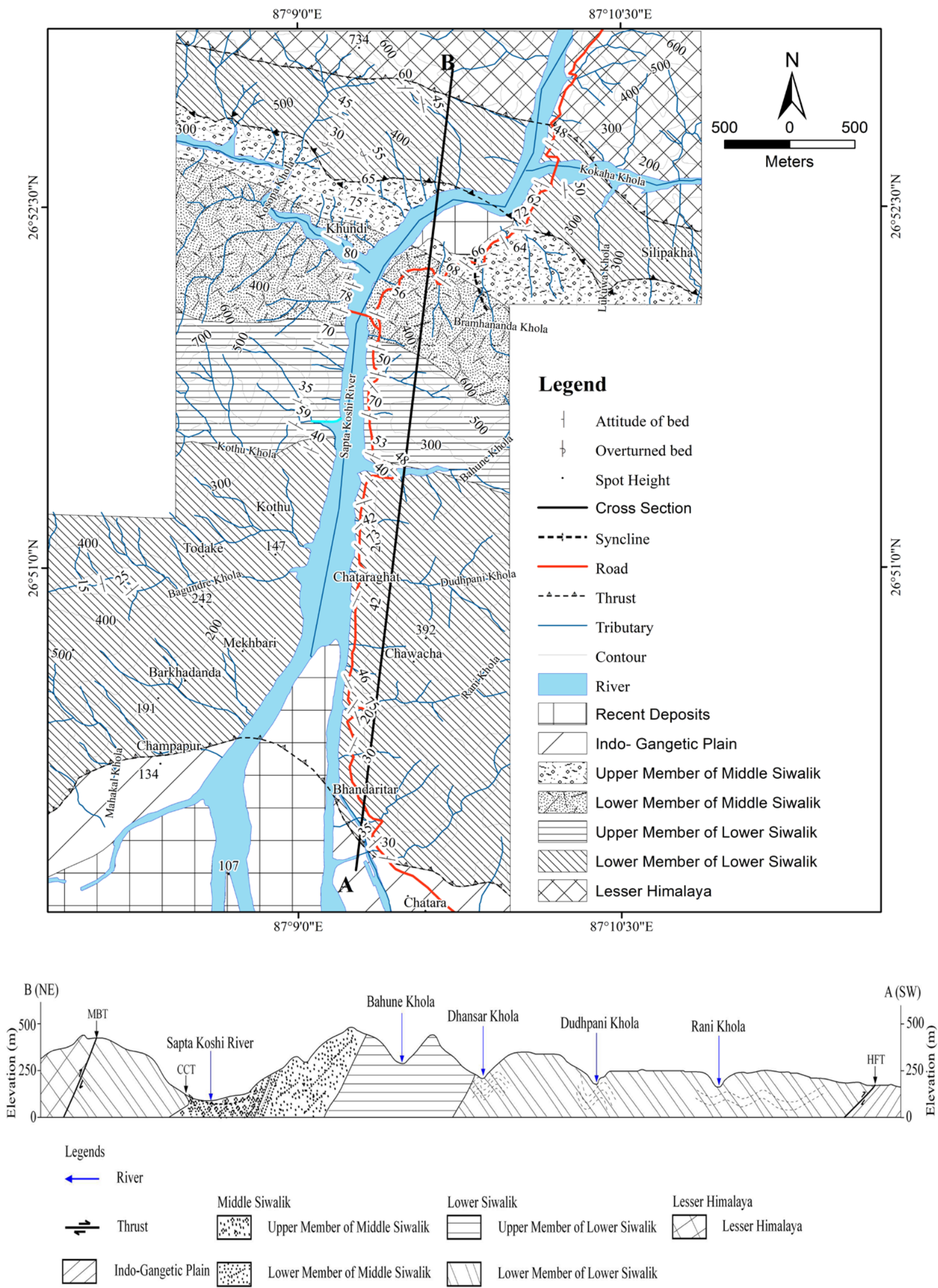

Fig. 2: Geological map of the study area with cross-section through A and B. 
$200 \mathrm{~cm}$ respectively. Sometimes the bed of siltstone and sandstone shows calcareous nature. The fossil plant leaves and vertebrates, and some coal lenses (up to $4 \mathrm{~cm}$ thick) are observed in greenish grey calcareous siltstone and light grey fine-grained sandstone respectively. Concordant petrified wood is also observed in the sandstone beds. It transitionally passes to the upper member at the Chatara area. The lower member of the Lower Siwalik at Barahakshetra region is bounded between the CCT and the MBT.

\section{Upper Member}

The rocks of this member are well-exposed in uphill from the Dhansar Khola to Barahaksherta. It consists of alternating beds of fine- to coarse- grained sandstones, variegated to dark grey mudstones and siltstones (Fig. 3b). The sequences of sandstone beds are up to $700 \mathrm{~cm}$ in thickness. The proportion of sandstone to mudstone increases towards the top, and a similar increase in grain size can be observed. Dark grey, greenish grey, bluish grey, siltstone beds up to $300 \mathrm{~cm}$ in thickness can be observed. The thickness of variegated to dark grey mudstone ranges from $15 \mathrm{~cm}$ to $660 \mathrm{~cm}$. Crosslamination, bioturbation, petrified wood and/or coal lenses and fossiliferous horizon are common in this member. The contact between the upper member of Lower Siwalik and the Lower Member of the Middle Siwalik is transitional.

\section{Middle Siwalik}

The rocks of Middle Siwalik can be observed from the suspension bridge over the Sapta Koshi River at the Satra Namber up to the Barahakshetra Village. It is bounded on the north by the Central Churia Thrust (CCT) which carries the Lower Siwalik rocks over the Middle Siwalik rocks. This member comprises of pebbly sandstone, medium to coarse grained salt and pepper sandstone; bluish grey to grey, finegrained sandstone; greenish to grey siltstone, grey to black mudstone and shale. The total thickness of this formation is about $630 \mathrm{~m}$. On the basis of lithology, it is further divided into lower and upper members.

\section{Lower Member}

The rocks of this member is well-exposed at suspension bridge at the Satra Namber over the Sapta Koshi River, the Kosopa Khola and the Champakot village. The main lithology of this member is alternating beds of fine to coarse grained 'salt-and-pepper' sandstone with greenish to bluish grey siltstone and dark mudstone (Fig. 3c). This member contains plant fossils in siltstones and shale, and coal lenses in salt-andpepper sandstones.

\section{Upper Member}

The transitional contact between the Lower Member and the Upper Member of the Middle Siwalik can be observed in the Bramhananda Khola at left bank and $50 \mathrm{~m}$ upstream from the Kosopa Khola at right bank of the Sapta Koshi River. It consists of coarse to very coarse grained 'salt and pepper' sandstone, pebbly sandstone, siltstone and mudstone. The beds of coarse to very coarse grained 'salt and pepper' pebbly sandstone are up to $12 \mathrm{~m}$ in thickness (Fig. 3d). The pebbly sandstone contains the clasts of quartzite, gneiss, and limestone and clast size up to $2 \mathrm{~cm}$ diameter. Fine grained, bluish grey, dark grey, light grey sandstone of thickness up to $300 \mathrm{~cm}$ are frequent. The siltstone beds are greenish grey, bluish grey, dark grey, black in color and thickness up to $270 \mathrm{~cm}$. The mudstone beds are dark grey, greenish grey in color ranging from 20 to $70 \mathrm{~cm}$ in thickness. The upper part of this member is marked by the presence of the CCT.

\section{Petrography}

The mineralogical composition of sandstones of the Siwalik in the study area are principally quartz, feldspar, biotite and rock fragments. The conclusion drawn from the samples taken from the study area is to distinguish the properties of the sandstone between the Lower Siwalik Formation and the Middle Siwalik Formation. It is essential to determine the original model composition. Several thin sections were prepared for the examination of the accurate original mineral composition, grain size, texture and are studied on the petrographic microscope.

\section{Lower Siwalik Sandstone}

\section{Sample No. 1}

Texture: The Lower Siwalik Sandstones are poorly sorted. The grain size ranges from $<0.01$ to $0.1 \mathrm{~mm}$ (Fig. $4 \mathrm{c}$ ). The clast compositions are ranges $60 \%$ and the cementing material ranging 30\%. Quartz and the feldspar grains are sub-rounded to sub-angular, however the larger quartz grains seems to be sub-rounded to rounded.

Composition: The mineral composition of the Lower Siwalik sandstone consists of quartz (20\%), feldspar (20\%), mica mineral $(50 \%)$ and other $(5 \%)$. The mica mineral are more dominant than the quartz and feldspar grain.

\section{Sample No. 2}

Texture: This sandstone is poor to moderately sorted. The quartz and feldspar grains are generally angular to sub-angular, the mica mineral are elongated. Some large grains of quartz are seems to be sub-rounded. The cementing material is unidentified but seems to be silica component. The proportion of matrix and cementing components are $90 \%$ and $10 \%$ respectively.

Composition: Quartz (40\%), feldspar (30\%), biotite (15\%) and other unidentified grains (15\%). The quartz and feldspar are usually larger than the other grains, and are the dominant components in the sandstone (Fig. 4d).

\section{Middle Siwalik Sandstone}

The Middle Siwalik sandstones are moderately to wellsorted. The proportion of clast matrix is greater than the cementing material (95\%-5\%). The angular to sub-angular quartz grain have size of 0.05 to $0.2 \mathrm{~mm}$ (Fig. 4e).

Composition: Quartz (55\%), biotite (25\%), muscovite (15\%) and plagioclase $(5 \%)$. 
a

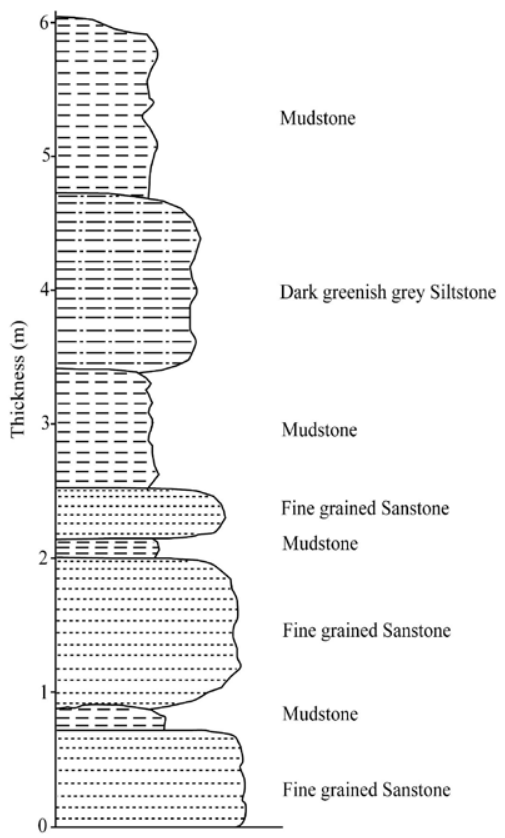

b

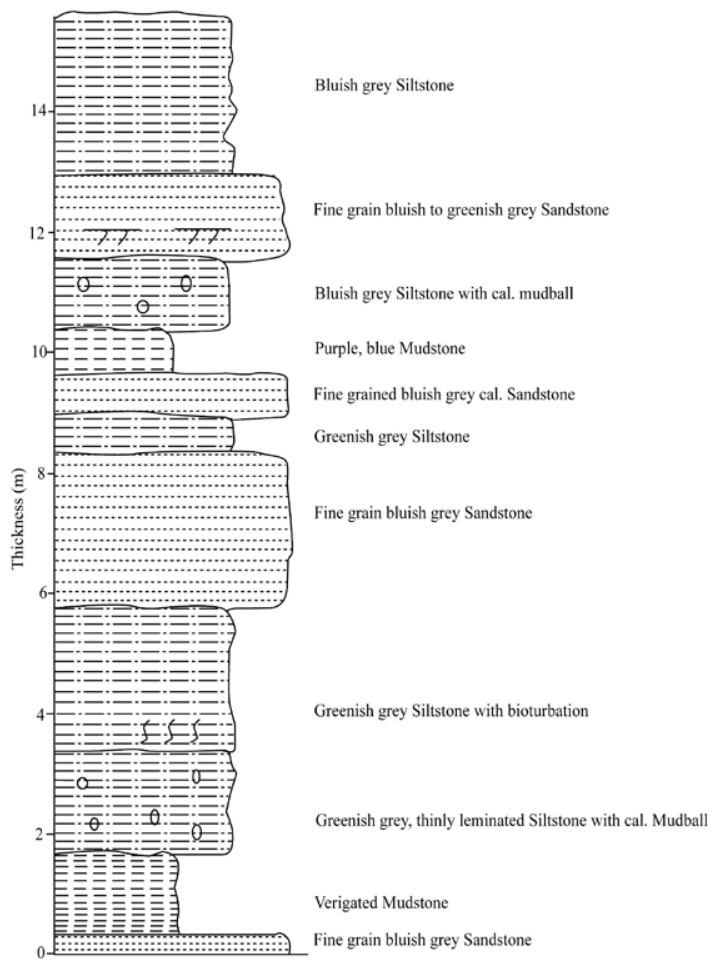

c

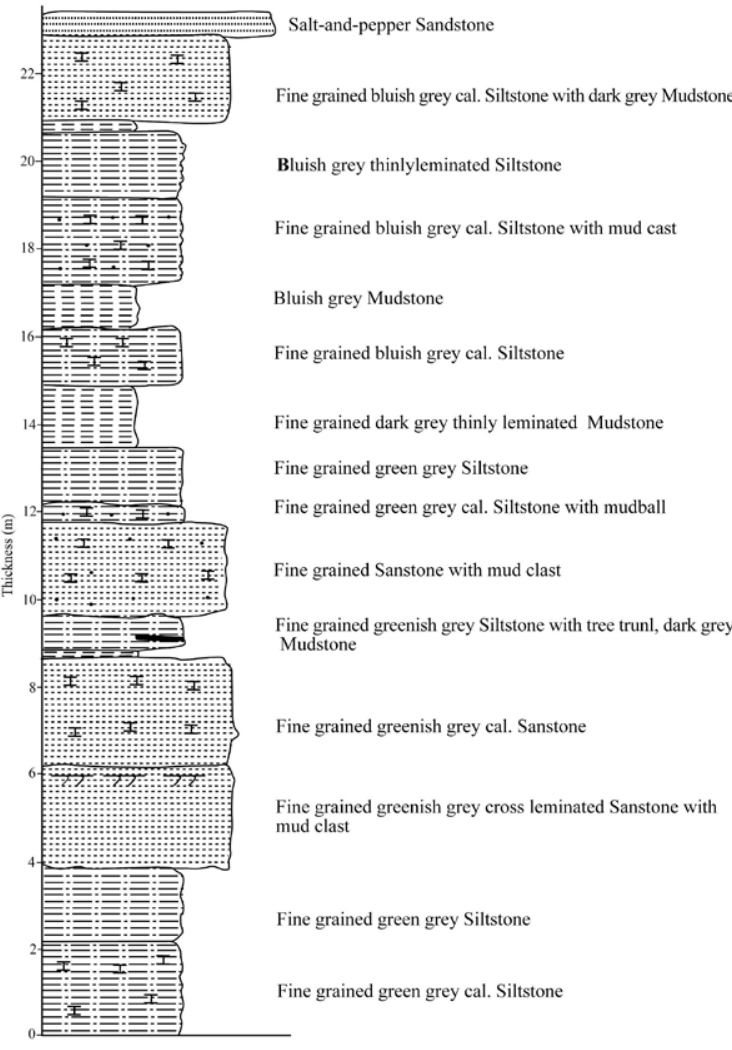

d

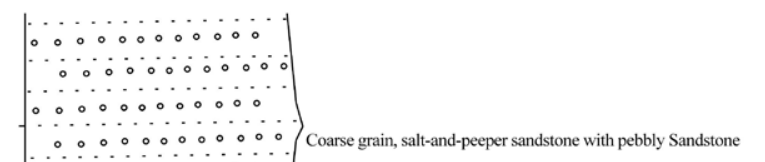

00000000000

0 o o o o o

$\because \because \because \because \because 0 \% 0$

0000000000

$\because 00000000$

$\because 000000$

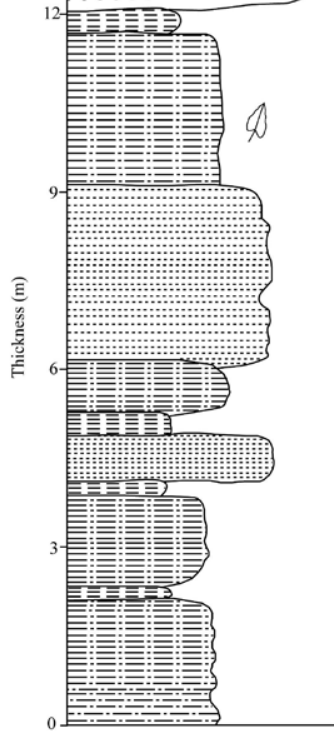

Dark greenish grey Mudstone

Dark to bluish grey Siltston

Coarse salt-and-pepper Sandstone

Bluish grey Siltstone

Dark greenish grey Mudstone

Coarse salt-and-pepper Sandstone

Dark grey Mudstone

Bluish-dark grey Siltstone

Grey Mudstone

Dark to bluish grey Siltstone

Fig. 3: Columnar section representing: (a). Lower member of Lower Siwalik at Dudhpani Khola, (b). Upper member of Lower Siwalik at Dhansar Khola, (c). Lower member of Middle Siwalik at Kosopa Khola, (d). Upper member of Middle Siwalik at Bramhananda Khola. 

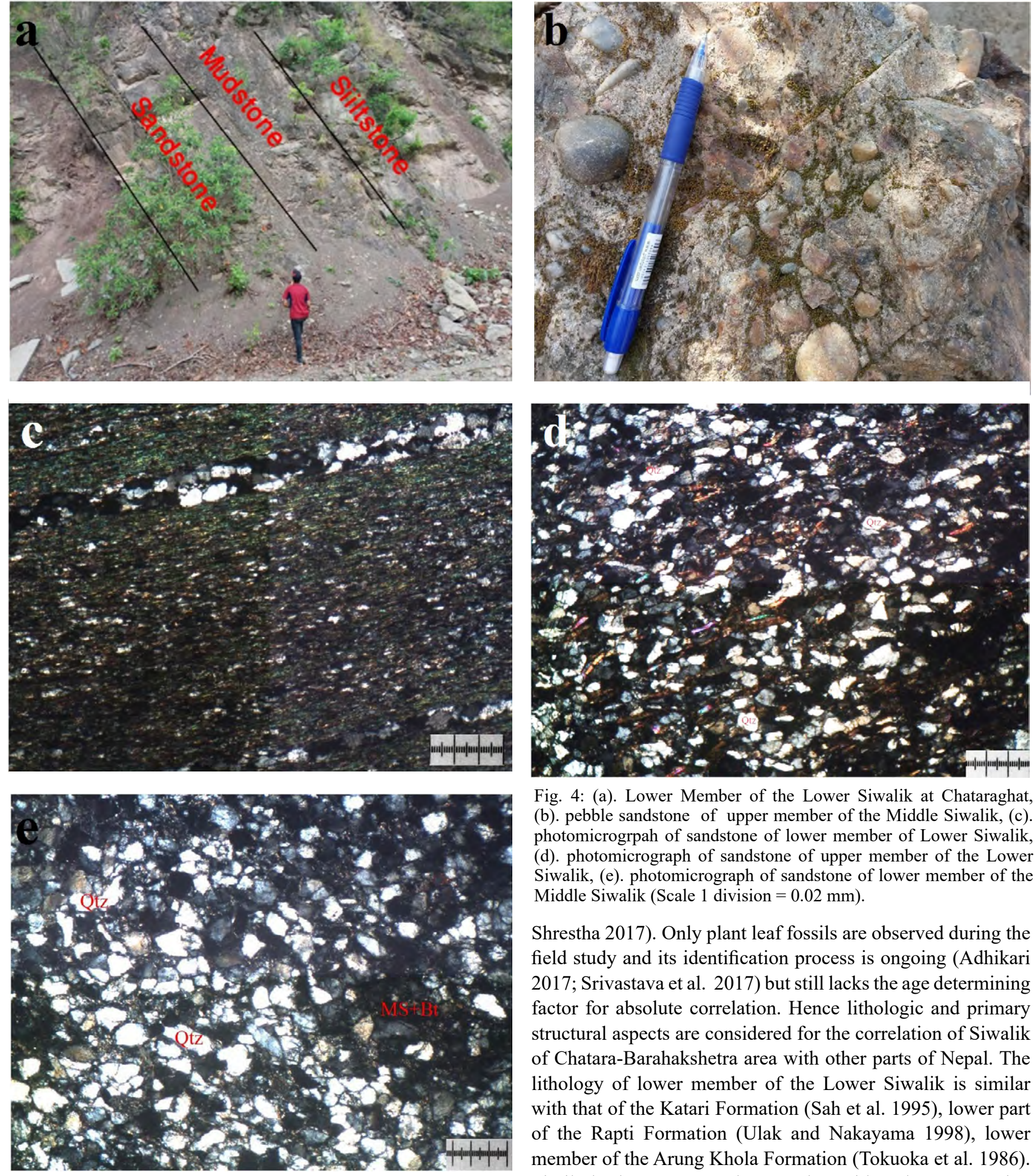

\section{Correlation}

The Siwalik rocks of the Chatara-Barahakshetra area are correlated with the other sections of the Siwalik Group (Table 1). Due to lack of absolute age, the correlation is based on the lithological similarity. Previous researchers have attempted the correlation on lithologic basis too (Ulak 2004; Adhikari 2017;

Fig. 4: (a). Lower Member of the Lower Siwalik at Chataraghat, (b). pebble sandstone of upper member of the Middle Siwalik, (c). photomicrogrpah of sandstone of lower member of Lower Siwalik, (d). photomicrograph of sandstone of upper member of the Lower Siwalik, (e). photomicrograph of sandstone of lower member of the Middle Siwalik $($ Scale 1 division $=0.02 \mathrm{~mm})$.

Shrestha 2017). Only plant leaf fossils are observed during the field study and its identification process is ongoing (Adhikari 2017; Srivastava et al. 2017) but still lacks the age determining factor for absolute correlation. Hence lithologic and primary structural aspects are considered for the correlation of Siwalik of Chatara-Barahakshetra area with other parts of Nepal. The lithology of lower member of the Lower Siwalik is similar with that of the Katari Formation (Sah et al. 1995), lower part of the Rapti Formation (Ulak and Nakayama 1998), lower member of the Arung Khola Formation (Tokuoka et al. 1986). Similarly the upper member matches with Kakaru Formation (Sah et al. 2000), upper part of the Rapti Formation (Ulak and Nakayama 1998) upper member of the Arung Khola Formation (Tokuoka et al. 1986) and Jungli Khola Member of Chor Khola Formation (Dhital et al. 1995). The Lower and upper Member of the Middle Siwalik can be correlated with the Amlekhgunj Formation (Ulak and Nakayama 1998), Lower and Upper member of the Binai Khola Formation, Ghurmi Formation 
and Belsoth Formation (Sah et al. 2000), Shivgarhi Member of Chor Khola Formation and Surai Khola Formation (Dhital et al. 1995) respectively.

\section{Geological Structures}

The geological structures of the area has been studied as primary and secondary structures.

\section{Primary structures}

The primary sedimentary structures are abundantly scattered throughout the study area. The cross trough laminations (Fig $5 b$ ), cross beddings, climbing ripples, current ripples, load casts (Fig. 5c) suggests the environment of depositions, flow directions as well as some sort of younging directions. The cross beddings are common in sandstones of Lower Siwalik and the Middle Siwalik. The load cast, a pressure structure can be observed in the Bramhananda Khola area which represents the upper member of the Middle Siwalik. The stratigraphy prepared, the major structural predictions are governed by the study of these primary structures.
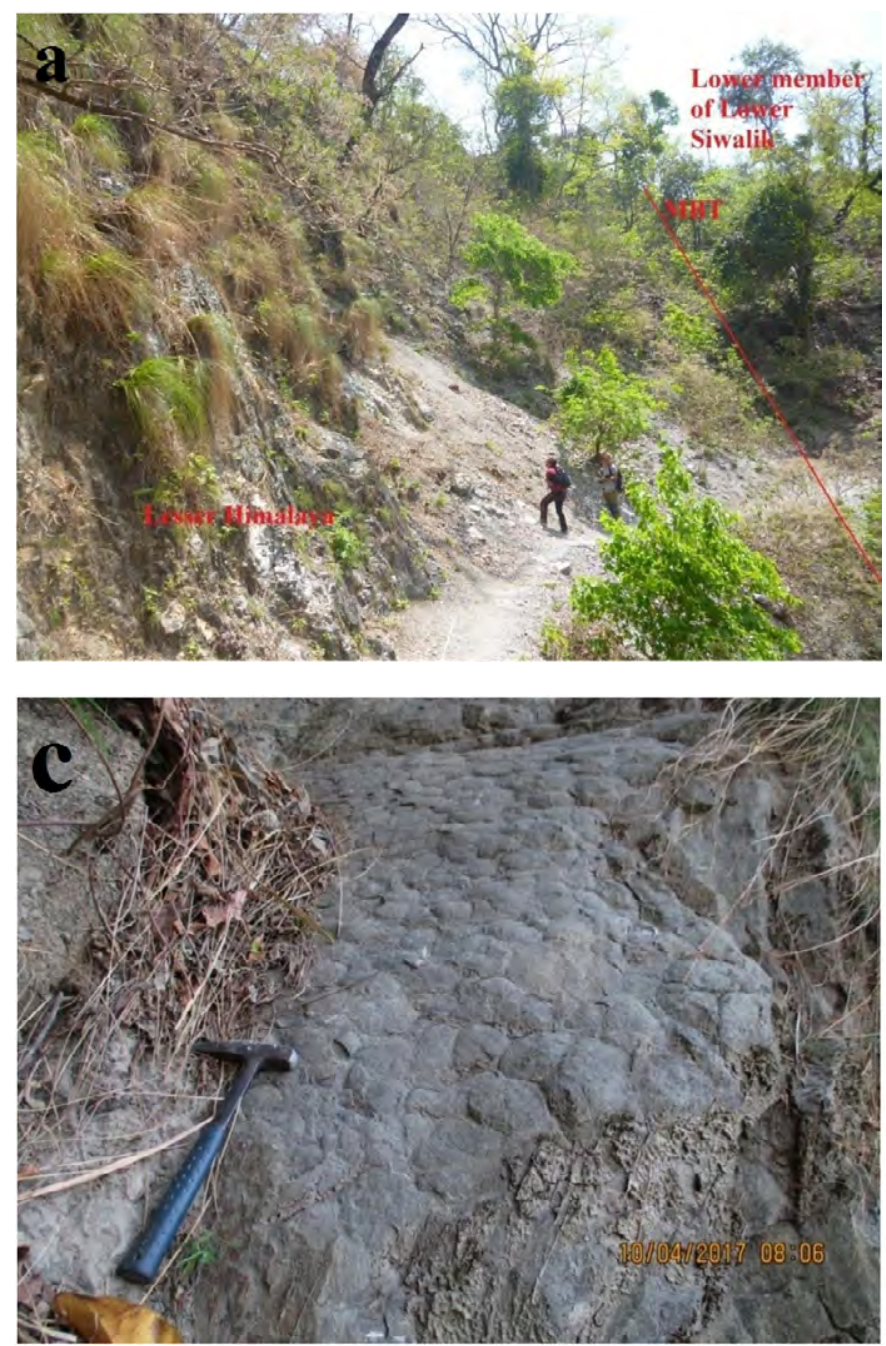

\section{Secondary structures}

Tectonically the Siwalik of Chatara-Barahakshetra is bounded by the Himalayan Frontal Thrust (HFT) and the Main Boundary Thrust (MBT) in south and north respectively. The HFT separates the older sequences of sedimentary rocks in the north from the younger Quaternary alluvial fan deposits in the south, and it can be traced around the Chatara, Champapur area. The override of the Siwalik rocks over the younger sediments of the Gangetic Plain proves the presence of thrust (Ulak 2004). At present, the HFT is moderately $\left(<45^{\circ}\right)$ northward dipping thrust. The MBT is a steep $\left(>60^{\circ}\right)$ and northward dipping thrust along which the older rock of the Lesser Himalaya in the north overrides the younger sedimentary rocks of the Siwalik of in the south (Fig. 5a). In the study area, it is well exposed around the Kokaha Khola, the Sapta Koshi River, Barahakshetra. The lower member of the Lower Siwalik lies in the footwall of the thrust and on the hanging wall the Lesser Himalaya which consists of Precambrian dolomite and the Gondwana sedimentary rocks. The exposures are highly deformed and crushed on the MBT zone. The topography changes from
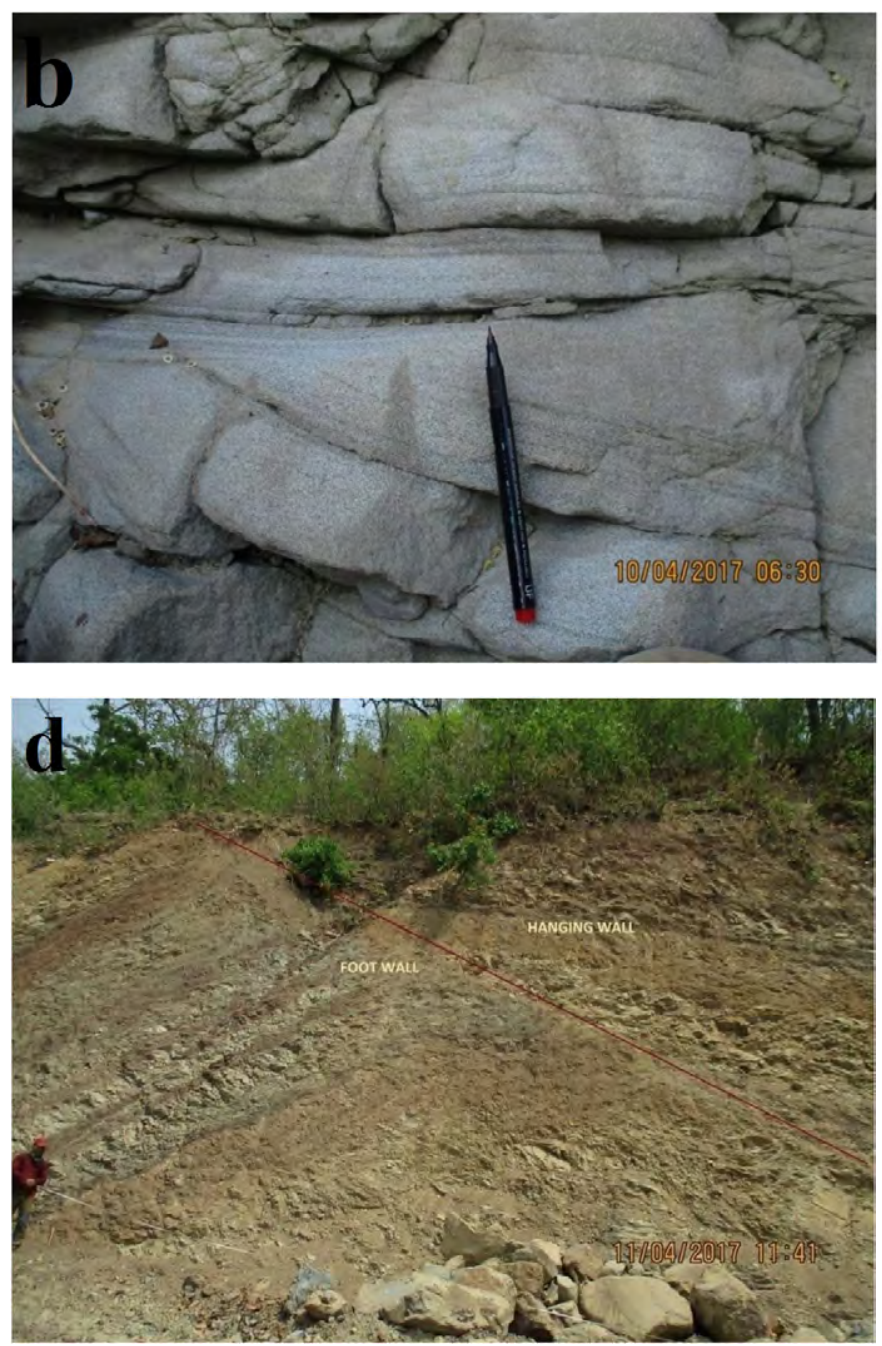

Fig. 5: Field photographs showing the structures. (a). Boundary between Siwalik and Lesser Himalaya 500 m upstream Sapta Koshi River from Barahakshetra Temple, (b). Trough cross lamination just south of CCT showing top to the south normal beds of sandstone, (c). Load cast near the Bramhanada Khola bridge, (d). Local fault observed about $200 \mathrm{~m}$ towards the Chatara from the Sapta Koshi River bridge. 
Table 1: Lithological correlation of the present study with the other sections of Siwalik.

\begin{tabular}{|l|l|l|l|l|l|l|}
\hline $\begin{array}{l}\text { Chaatara- } \\
\text { Barahakshetra } \\
\text { Eastern Nepal }\end{array}$ & $\begin{array}{l}\text { Katari area, } \\
\text { eastern Nepal } \\
\text { (Sah et al. 2000) }\end{array}$ & $\begin{array}{l}\text { Hetauda section, } \\
\text { central Nepal (Sah } \\
\text { et al. 1994; Ulak } \\
\text { and Nakayama } \\
\text { 1998) }\end{array}$ & $\begin{array}{l}\text { Arung Khola- Binai } \\
\text { Khola section, } \\
\text { west- central Nepal } \\
\text { (Tokuoka et al. 1986, } \\
\text { 1988, 1990) }\end{array}$ & $\begin{array}{l}\text { Surai Khola Section, west } \\
\text { Nepal (Cornivus and Nanda } \\
\text { 1994; Dhital et al. 1995) }\end{array}$ \\
\hline $\begin{array}{l}\text { Middle } \\
\text { Siwaliks }\end{array}$ & $\begin{array}{l}\text { Upper } \\
\text { Member }\end{array}$ & Belsoth Formation & $\begin{array}{l}\text { Upper part of } \\
\text { the Amlekhgunj } \\
\text { Formation }\end{array}$ & Middle & $\begin{array}{l}\text { Binai Khola } \\
\text { Formation }\end{array}$ & Surai Khola Formation \\
\cline { 2 - 4 } & $\begin{array}{l}\text { Lower } \\
\text { member }\end{array}$ & Ghurmi Formation & $\begin{array}{l}\text { Lower part of } \\
\text { the Amlekhgunj } \\
\text { Formation }\end{array}$ & Lower & $\begin{array}{l}\text { Shivgarhi Member of Chor } \\
\text { Khola Formation }\end{array}$ \\
\hline $\begin{array}{l}\text { Lower } \\
\text { Siwalik }\end{array}$ & $\begin{array}{l}\text { Upper } \\
\text { Member }\end{array}$ & Kakaru Formation & $\begin{array}{l}\text { Upper part of the } \\
\text { Rapti Formation }\end{array}$ & Upper & $\begin{array}{l}\text { Arung Khola } \\
\text { Formation }\end{array}$ & $\begin{array}{l}\text { Jungli Khola Member of Chor } \\
\text { Khola Formation }\end{array}$ \\
\cline { 2 - 4 } \cline { 3 - 4 } & $\begin{array}{l}\text { Lower } \\
\text { Member }\end{array}$ & Katari Formation & $\begin{array}{l}\text { Lower part of the } \\
\text { Rapti Formation }\end{array}$ & Lower & & Bankas Formation \\
\hline
\end{tabular}

gentle to steep, pressures ridge can also be observed. At the Barahakshetra, Kothu village region rocks of the lower member of the Lower Siwalik reappear over the rocks of the upper member of the Middle Siwalik, and this marks the presence of CCT. The CCT is overturned in the area and is marked by the cross beddings showing the south dipping normal bed at the thrust plane area (Fig. 5b). Several local scale normal and reverse faults can be observed in the study area. Some displacements are visible in outcrop scale some are identified by the lithological disturbances. The faults can be observed at Rani Khola area as well near the bridge over the Sapta Koshi River, at the suspension bridge of Satra Namber (Fig. 5d). A major syncline can be observed near the Bramhananda Khola which is east-west trending and shows extension eastward. Numerous outcrop scale folds can be observed on the study area. The folds are present more in the Lower Siwalik rock sequence i.e. from Chatara upto Dhansar Khola. In the rocks of the Middle Siwalik the area from Barahakshetra upto the Satra Namber several folds can be observed. Maximum numbers of folds are eastwest trending but some are north south trending. The average axis of the folds using the field data has been calculated using the stereonet which is $289^{\circ} / 26^{\circ}$ (Fig. 6).

\section{DISCUSSION AND CONCLUSIONS}

Lithologically the study area consists of variegated mudstone, siltstone, fine sandstone at the bottom section whereas medium to coarse salt-and-pepper sandstone, pebbly sandstone at the top section (Fig. 7). Stratigraphically, the area has been subdivided into the Lower Siwalik and the Middle Siwalik. The Lower Siwalik has been further subdivided into the Lower and the Upper Members on the basis of increasing sandstone proportion over the mudstone. Similarly, the Middle Siwalik has also been subdivided into the Lower and Upper Members on the basis of presence of pebbles on sandstone.The mineral composition of the Lower Siwalik sandstones consist
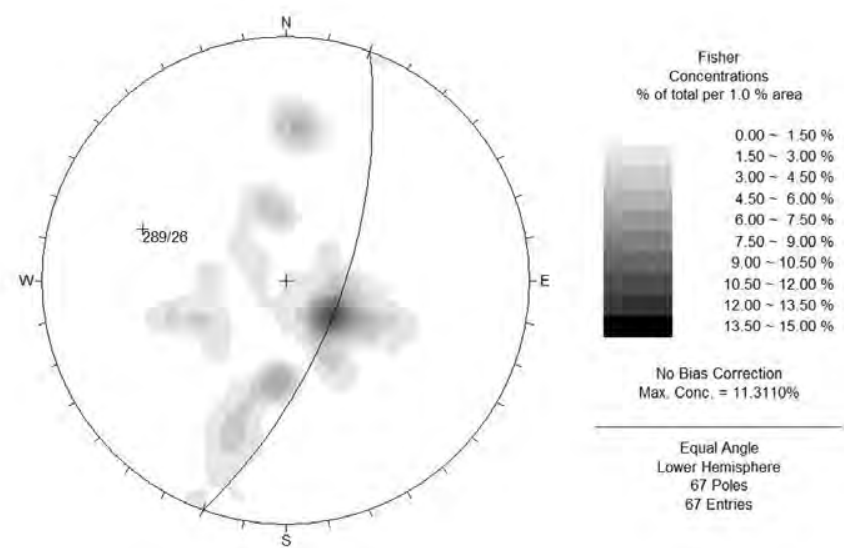

Fig. 6: The average axis of the folds of study area.

of mica-mineral, quartz, feldspar and cementing material. The quartz grains are sub-rounded to sub-angular. The mica mineral is greater than the quartz and feldspar. The grain size distribution is poorly shorted. The mica-mineral percent decrease from bottom to top of the strata. The moderately to well-sorted sandstone of the Middle Siwalik Formation consists the mineral composition of the quartz, plagioclase, rock fragments. The angularly of the grain is increase than the Lower Siwalik sandstone.

The HFT, MBT, and CCT are the major thrust observed in the area. The lithological contrast and the overriding of the older rock sequence over younger rocks indicate the presence of thrust. The CCT in the study area seems to be overturned shown by the south dipping normal beds of upper member of the Middle Siwalik (Fig. 5b). The major folds marked by Dhakal (2001) and Ulak (2004) seem to be minor outcrop scale folds in the study area. A syncline is present near the Brahmananda Khola. Most of the folds observed in the area are trending eastwest direction, but some are north south trending which indicates multiple stage deformations. 


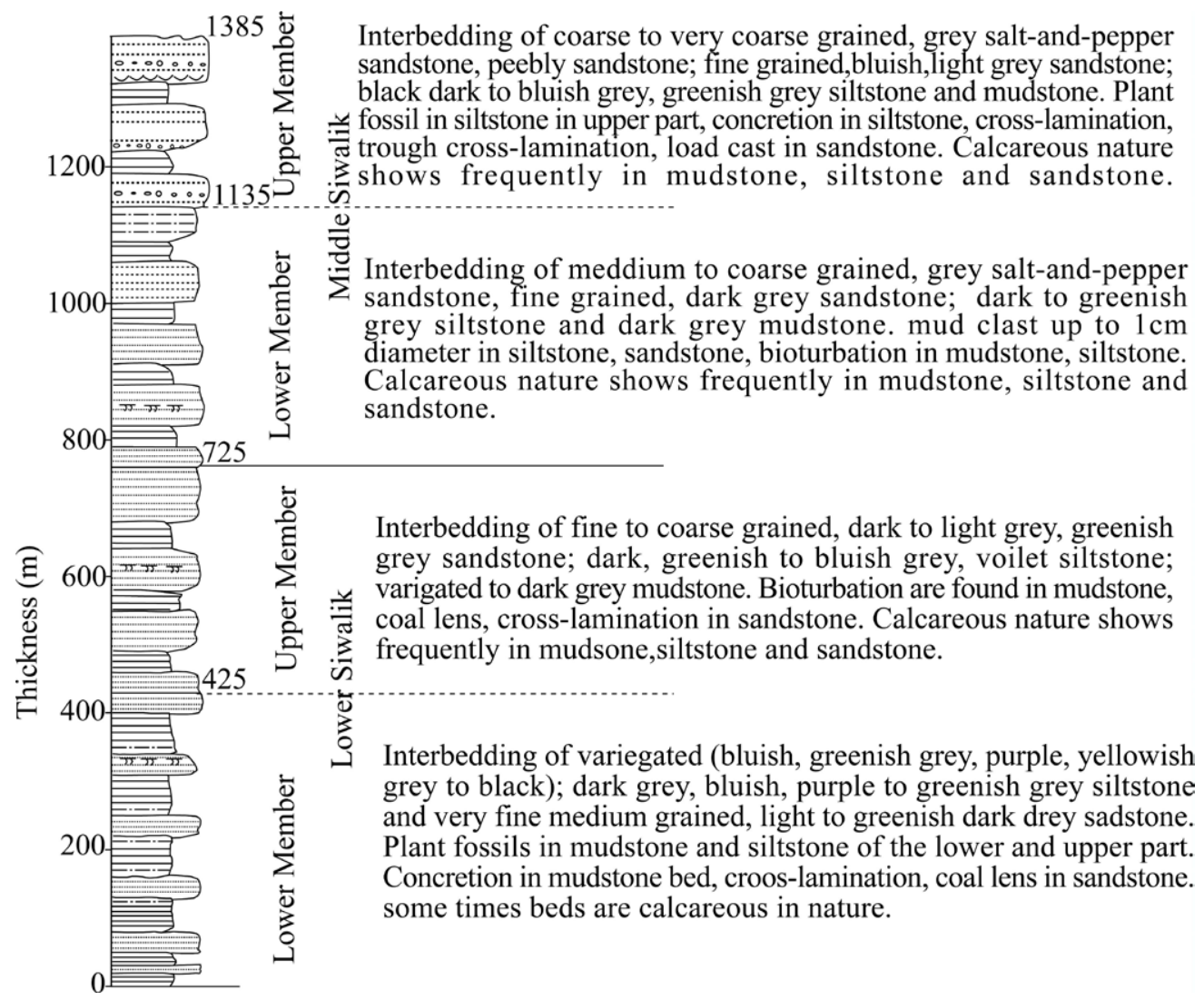

Fig. 7: Generalized lithostratigraphy of the Siwalik in Chatara-Barahakshetra area.

\section{ACKNOWLEDGEMENTS}

This work is mainly based on the MSc dissertation of DA submitted at the Central Department of Geology, Tribhuvan University. The authors are thankful to all the peoples who helped during the field work and lab analysis especially the Central department of Geology batch 2071.

\section{REFERENCES}

Adhikari, P., 2017. Geology and paleontology of ChataraBarahakshetra area, eastern Nepal. Unpublished, M.Sc. dissertation, Central Department of Geology, Tribhuvan University, Nepal (Unpublished), 83 p.

Auden, J.B., 1935. Traverses in the Himalaya. Records of Geological Survey of India, v. 69, pp. 123-167.

Bouilhol, P., Jagoutz, O., Hanchar, J.M., and Dudas, F.O., 2013. Dating the India-Eurasia collision through arc magmatic records. Earth Planet. Sci. Lett., v. 366, pp. 163-175.

Chatterjee, S., Goswami, A., and Scotese, C.R., 2013. The longest voyage: tectonic, magmatic, and paleoclimatic evolution of the Indian plate during its northward flight from Gondwana to Asia. Gond. Res., v. 23, pp. 238-267.

Clift, P., Carter, A., Krol, M., and Kirby, E., 2002. Constraints on India-Eurasia collision in the Arabian sea region taken from the Indus Group, Ladakh Himalaya, India: the tectonic and climatic evolution of the Arabian Sea region. Jour. Geol. Soc. London, v. 195 , pp. 97-116.

Colbert, E.H., 1934. A new Rhinoceros from the Siwalik beds of India. American Museum Novitates, v. 635, pp. 1-9.

Cornivus, G., and Nanda, A.C, 1994. Stratigraphy and paleontology of the Siwalik Group of Surai Khola and Rato Khola. Neues Jahrbuch für Geologie und Paläontologie, v. 191(1), pp. 25-68.

Dhakal, S., 2001. Geological investigation of the ChataraBarahakshetra area, eastern Nepal. Unpublished, M. Sc. dissertation, Central Department of Geology, Tribhuvan University, Nepal (Unpublished), 43 p.

Dhital, M.R., 1992. Lithostratigraphic comparison of three diamictite successions of Nepal Lesser Himalaya. Jour. Nepal Geol. Soc., v. 8 , pp. $43-54$.

Dhital, M.R., 2015. Geology of the Nepal Himalaya: regional perspective of the classic collided orogeny. Springer, Switzerland. $498 \mathrm{p}$.

Dhital, M.R., Gajurel, A.P., Pathak, D., Paudel, L.P., and Kizaki, K., 1995. Geology and structure of the Siwaliks and Lesser Himalaya in the Surai Khola Bardanda area, mid western Nepal. Bull. Dept Geol., Tribhuvan University, v. 4 (Sp. Issue), pp. 1-20.

Frank, W., and Fuchs, G.R., 1970. Geological investigations in west Nepal and their significance for the geology of the Himalayas. Geologische Rundschau, v. 59, pp. 552-580.

Gansser, A., 1964. Geology of the Himalayas. Interscience Publicaltion Wiley, London, $289 \mathrm{p}$.

Hagen, T., 1969. Report on Geological Survey of Nepal. Neue Denkschriften der Schweizerischen Naturforschenden Gesellschaft, v. 86(1), 185 p.

Kumar, K., 1985. Fundamentals of Historical geology and stratigraphy of India. Wiley Eastern Limited, 254 p.

Martin, A.J., DeCelles, P.G., Gehrels, G.E., Patchett, P.J., and Isachsen, C. 2005. Isotopic and structural constraints on the location of the Main Central Thrust in the Annapurna Range, central Nepal Himalaya. Geol. Soc. America Bull., v. 117, pp. 926-944. 
Paudel, L.P., 2011. Study of minerals and rocks in thin section. GeoScience Innovations Private Limited, Kathmandu, Nepal, 120 p.

Pilgrim, G.E., 1913. The correlation of the Siwaliks with mammal horizons of Europe. Records Geol. Surv, India, v. 43(4), pp. 264-326.

Pilgrim, G.E., 1910. Preliminary note on a revised classification of the tertiary freshwater deposits of India. Records Geol. Surv, India, v. 40(3), pp. 185-205.

Sah, R.B., Ulak, P.D., Gajurel, A.P., and Rimal, L.N., 1994. Lithostratigarphy of Siwaliks sedeiments of AmlekhganjHetauda area, sub-Himalaya of Nepal. Him. Geol., v. 15, pp. 37-48.

Sah, R.B., Yadav, B., and Thakuri, N., 1995. The lithostratigraphy of Siwaliks of Katari area, east central Sub-Himalaya, Nepal. Jour. Nepal Geol. Soc., v. 12, pp 6-7.

Sah, R.B., Thakuri, N., and Yadav, B., 2000. Lithostratigraphy of Siwalik succession of Katari area, Sub-Himalaya, eastern Nepal. Jour. Strat. Asso. Nepal, v. 2, pp. 18-28.

Sah, R.B., 2015. Stratigraphic monograph II: Stratigraphy of Nepal. Jour. Strat. Asso. Nepal, v. 10, 194 p.

Searle, M., Corfield, R.I., Stephenson, B., and McCarron, J., 1997. Structure of the North Indian continental margin in the LadakhZanskar Himalayas: implications for the timing of obduction of the Spontang ophiolite, India-Asia collision and deformation events in the Himalaya. Geol. Mag., v. 134, pp. 297-316.

Shrestha, K., 2017. Lithostratigraphy and non-metallic mineral resources of the Machuwatar- Chatara area, Sunsari-Dhankuta Districts, eastern Nepal. Unpublished, M.Sc. dissertation, Central Department of Geology, Tribhuvan University, Nepal (Unpublished), $55 \mathrm{p}$.

Srivastava, G., Adhikari, P., Meherotra, R.C., Paudel, L., Uhl, D., and Paudayal, K.N., 2017. Dipterocarpus Gaertn.
(Dipterocarpaceae) leaf from the Middle Siwalik of eastern Nepal and its phytogeographic and climatic significance. Jour. Nepal Geol. Soc., v. 53, pp. 39- 46.

Stöcklin, J., 1980. Geology of Nepal and its regional frame. Jour. Geol. Soc. London, v. 137, pp. 1-34.

Sunuwar, S.C., 1993. Geology of Tribeni-Barahakshetra area, Sunsari-Dhankuta District, eastern Nepal. Unpublished, M.Sc. dissertation, Central Department of Geology, Tribhuvan University, Nepal (Unpublished), $94 \mathrm{p}$.

Tokuoka, T., Takeda, S., Yoshida, M., and Upreti, B.N., 1988. The Churia (Siwalik) Group in the western part of the Arung Khola area, west central Nepal. Memorier Faculty of Science, Shimane University, v. 22, pp. 131-140.

Tokuoka, T., Takayasu, K., Yoshida, M., and Hisatomi, K., 1986. The Churia (Siwalik) Group of the Arung Khola area, west cental Nepal. Memorier Faculty of Science, Shimane University, v. 22, pp. 135- 210 .

Tokuoka, T., Takayasu, K., Hisatomi, K., Yamajaki, H., Tanaka, S., Konomatus, M., Sah, R.B., and Roy, S.M., 1990. Stratigraphy and geological structures of the Churia (Siwalik) Group in the Tinau Khola-Binai Khola area, west central Nepal. Memorier Faculty of Science, Shimane University, v. 24, pp. 72- 88.

Ulak, P.D., and Nakayama, K., 1998. Lithostratigraphy and evolution of the fluvial style in the Siwalik Group in Hetauda, Bakiya Khola area, central Nepal. Bull. Dept. Geol., Tribhuvan University, v. 6, pp. 1-14.

Ulak, P.D., 2004. Evolution of fluvial system in Siwalik Group of Chatara-Barahakshetra area, east Nepal Himalaya. Jour. Nepal Geol. Soc., v. 30, pp. 67-74.

Yin, A., 2006. Cenozoic tectonic evolution of the Himalayan orogeny as constrained by along- strike variation of structural geometry, exhumation history, and foreland sedimentation. Earth Sci. Rev., v. 76, pp. 1-131. 